\title{
Evaluation of TOM-CAST in Timing Fungicide Sprays for Management of Alternaria Blight on American Ginseng
}

\author{
S. N. Hill, Graduate Research Assistant, and M. K. Hausbeck, Professor, Department of Plant Pathology, Michigan \\ State University, East Lansing 48824
}

\begin{abstract}
Hill, S. N., and Hausbeck, M. K. 2008. Evaluation of TOM-CAST in timing fungicide sprays for management of Alternaria blight on American ginseng. Plant Dis. 92:1611-1615.

Alternaria panax incites blighting of the foliage, peduncles, and drupes of cultivated American ginseng (Panax quinquefolium). A disease forecaster (TOM-CAST), originally developed to predict leaf blight caused by A. solani on tomato, was evaluated for management of A. panax in commercial ginseng gardens. For 3 years, fungicide sprays initiated by TOM-CAST (using 10 and 15 disease severity value thresholds) were compared with sprays applied at 7- and 10-day intervals. Three fungicide programs were evaluated: (i) chlorothalonil alone, (ii) chlorothalonil alternated with pyraclostrobin, and (iii) copper hydroxide alternated with pyraclostrobin. As many as 10 fewer fungicide applications were made when using TOM-CAST or the 10-day programs. Although select TOM-CAST treatment programs were comparable with the 7-day schedule in limiting foliar disease, only the 7-day applications adequately protected drupe and seed yield. Both A. panax and A. alternata were recovered from drupe tissues and seed coats. Only A. alternata was recovered from endosperm halves. Ginseng seed yield and quality is an important consideration when assessing fungicide programs.
\end{abstract}

Additional keywords: integrated pest management, reduced-risk fungicides

American ginseng (Panax quinquefolium) is a perennial herb grown primarily for the medicinal properties of its root (24). Currently, more than $95 \%$ of the cultivated commercial ginseng in the United States is grown in Wisconsin (1), totaling $\$ 50$ to $\$ 75$ million annually (11). Ginseng is grown on a raised plant bed under a natural tree or artificial black woven polypropylene canopy (24). The shade required by the crop and the dense plant spacing create a microclimate with limited air movement, increased temperatures, and extended leaf wetness periods that are favorable for foliar pathogens.

The most common foliar disease of ginseng is Alternaria blight, caused by Alternaria panax Whetzel (22). This disease is a yearly problem for ginseng growers in Wisconsin (22) and Michigan (11). Alternaria blight also occurs in other ginsenggrowing regions, including Alberta, Canada $(7,8)$, West Virginia (28), North Carolina (9), Oregon, and Washington (25). Typical foliar symptoms include necrotic lesions with dark-brown margins and yellow-green halos (22). Brown lesions often develop on the stem just above the soil line

Corresponding author: Mary Hausbeck

E-mail: hausbec1@msu.edu

Accepted for publication 11 August 2008.

doi:10.1094/PDIS-92-12-1611

(C) 2008 The American Phytopathological Society and cause girdling (5). Infected drupes may develop a water-soaked appearance followed by the development of brown mycelium and pathogen sporulation. Infection of the root by A. panax is rare (22); however, root weight can be reduced when blighting of the leaves and stem causes premature defoliation.

A. panax can survive as conidia or mycelia in infected plant residue, on straw mulch, or in and on seed (16). In the spring, overwintered conidia may spread to and infect emerging healthy plants via rain splashing or air currents. Under favorable conditions, blight development and conidial production can occur in 5 to 7 days (30). Optimum conidial production occurs with temperatures ranging from 18 to $25^{\circ} \mathrm{C}$ $(5,30)$. Leaf wetness parameters for $A$. panax are unknown. However, researchers have shown that conidia can germinate on leaf tissue within 1 to $2 \mathrm{~h}$ when incubated at $25^{\circ} \mathrm{C}$ and $70 \%$ relative humidity (26).

Cultural strategies to manage Alternaria blight include increasing plant spacing to enhance air circulation, removing infected foliage, and replacing mulch in the affected area (9). However, these strategies are not practical and would not preclude the reintroduction of inoculum via air currents. Previous researchers have investigated the use of biocontrols as alternatives to traditional fungicides. Burkholderia cepacia AMMD (Pseudomonas cepacia strain AMMD) was found to effectively inhibit Alternaria leaf and stem blight under growth-chamber conditions. However, the biocontrol agent did not adequately reduce disease under field conditions due to poor survival on leaf surfaces $(14,21)$.

Currently, the reduced-risk strobilurin fungicides azoxystrobin and pyraclostrobin are used in alternation with either chlorothalonil or mancozeb (11). Chlorothalonil and mancozeb have been available to Wisconsin and Michigan ginseng growers through yearly Section 18 Emergency Exemption labels. Iprodione is also registered for the control of Alternaria blight on ginseng and can be effective. However, following control failure in 1987, an iprodione-resistant Alternaria population was identified in Wisconsin (27) and use of this product declined.

Managing Alternaria blight is a priority of the ginseng industry in Michigan and Wisconsin (11). When Alternaria blight is not controlled, complete defoliation of ginseng can occur (12,31). Using a forecasting system to assess disease potential associated with environmental conditions may reduce the number of fungicide applications needed per season $(3,4)$, lessen the chances for pathogens to develop fungicide resistance, and reduce grower costs. Disease-forecasting systems use weather variables (32) in conjunction with information about the biology and epidemiology of the pathogen to predict when conditions favor infection or disease development (15). TOM-CAST (developed for tomato disease forecasting) is a disease forecasting system that calculates daily disease severity values (DSVs) based on cumulative hours of leaf wetness and temperature. When the predetermined DSV threshold is reached, a fungicide is applied and the DSV is reset to zero (23). TOM-CAST has been successfully implemented to manage early blight on tomato $(6,23)$, purple spot on asparagus (18), and foliar blights on carrot (3), and studies have shown it to be useful on crops such as parsley (19) and celery (2).

Growers have expressed interest in identifying the environmental conditions that favor blight development and testing the TOM-CAST forecasting system as a tool to assist in timing fungicide applications (10). The objective of this study was to compare the TOM-CAST diseaseforecasting system with a calendar-based spray schedule using various fungicide programs for Alternaria blight control. The impact of these treatment programs on seed yield and health was also of interest. 


\section{MATERIALS AND METHODS}

TOM-CAST plot establishment. Field studies were conducted in a 3-year-old (2005) or 4-year-old (2006 and 2007) commercial ginseng garden located in Marathon County, WI. Each research site was 1.6 ha in area and consisted of a silt loam soil. Ginseng gardens were established from seed planted into 1.5 -m-wide raised beds that were 22 to $30 \mathrm{~cm}$ high. After seeding, beds were covered with $15 \mathrm{~cm}$ of straw mulch. Each year, woven polyethylene or polypropylene cloth panels providing $80 \%$ shade were suspended via 2- to 3-m posts over the plant beds to mimic woodlot conditions. Weeds were hand pulled.

Treatment plots consisted of 1.5 by $3 \mathrm{~m}$ raised beds, with $0.60-\mathrm{m}$ buffers on each end. Treatments were replicated four times in a randomized complete block design. Fungicides were applied with a $\mathrm{CO}_{2}$ backpack boom sprayer equipped with four 8006 nozzles spaced $45.7 \mathrm{~cm}$ apart, operating at $275.8 \mathrm{kPa}$, and delivering 467.7 liter/ha.

Weather monitoring and DSV calculation. Hourly measurements of air temperature and relative humidity were recorded using a WatchDog data recorder (series 450; Spectrum Technologies, Inc., Plainfield, IL). An unpainted WatchDog leaf wetness sensor (Spectrum Technologies, Inc.) was placed at a $45^{\circ}$ angle facing north within the upper $25 \%$ of the ginseng canopy. Data were downloaded weekly to a laptop computer using a computer program (Specware 6.01 and 7.01; Spectrum Technologies, Inc.). The program was set to record temperatures between 0 and $100^{\circ} \mathrm{C}$ and to detect leaf wetness whenever moisture was present on the grid. Rainfall was measured hourly using a tippingbucket rain collector (series 3554WD, Spectrum Technologies, Inc.).
For the TOM-CAST treatments, the hours of leaf wetness and the average air temperature during the periods of leaf wetness were used to determine a daily DSV ranging from 0 to 4 , corresponding to environmental conditions unfavorable to highly favorable for disease development, respectively (23). To accurately reflect the duration of a morning dew period, a 24-h monitoring period of $1100 \mathrm{~h}$ to $1100 \mathrm{~h}$ was used. Daily DSVs were accumulated until a threshold of 10 or 15 was reached, thus prompting a fungicide spray. After each fungicide application, the DSV was reset to zero for both of the TOM-CAST treatment programs.

Fungicide programs and application schedules. Fungicide programs included chlorothalonil (Bravo Weather Stik 6SC, $0.68 \mathrm{~kg}$ of active ingredient [a.i.]/ha; Syngenta Crop Protection, Inc., Greensboro, $\mathrm{NC}$ ), chlorothalonil (0.68 kg a.i./ha) alternated with pyraclostrobin (Cabrio 20EG, $0.07 \mathrm{~kg}$ a.i./ha; BASF Ag Products Research Triangle Park, NC), and copper hydroxide (Kocide 2000 54DF, $0.73 \mathrm{~kg}$ a.i./ha; DuPont Crop Protection, Wilmington, DE) alternated with pyraclostrobin (0.07 kg a.i./ha). Fungicide programs were initiated on 26 May 2005, 26 May 2006, and 5 June 2007. Subsequent applications were scheduled according to a calendarbased interval of every 7 or 10 days or according to the TOM-CAST disease forecaster using 10 or 15 DSVs. Fungicide programs were terminated on 9 September 2005, 13 September 2006, and 30 August 2007.

Disease assessment. Disease was assessed by counting the number of $A$. panax-infected plants in a $3-\mathrm{m}$ section of the bed on 31 August and 14 September 2005; 20 July, 3, 16, and 24 August 2006; and weekly from 3 July to 4 September
2007. Data were subjected to analysis of variance (ANOVA) and a StudentNewman-Keuls significant difference test $(P=0.05)$ was used to compare treatment efficacy (Statistical Analysis Software [SAS] 9.1.3; SAS Institute, Inc., Cary, NC) (20). The area under the disease progress curve (AUDPC) was calculated according to the methods of Shaner and Finney (29) to express the yearly cumulative numbers of infected plants throughout the seasons. The cumulative AUDPC values for each fungicide program and application interval were subjected to ANOVA and a StudentNewman-Keuls significant difference test $(P=0.05$; SAS 9.1.3) was used to compare treatment efficacy. Treatments were also assessed for phytotoxicity.

At the completion of the 2007 TOMCAST trial, drupes within the treatment and control plots were harvested. After recording the fresh weights for each plot, 20 drupes per replicate of each treatment and control were selected for fungal assessment. The remaining drupes were placed in 3.8-liter plastic zip bags and stored at $37^{\circ} \mathrm{C}$ for 2 weeks. Selected drupes were soaked in a $70 \%$ ethanol solution for $1 \mathrm{~min}$ and allowed to air dry in a sterile laminar flow hood. Portions of drupe tissue were aseptically excised and embedded in water agar (16 g agar/liter) plates (100 by $15 \mathrm{~mm}$ ) amended with ampicillin $(2 \mathrm{ml} /$ liter $)$ and incubated at $25^{\circ} \mathrm{C}$ under fluorescent lighting.

Seed of the respective drupe samples were also soaked in a $70 \%$ ethanol solution for $1 \mathrm{~min}$ and allowed to air dry in a sterile laminar flow hood. Following transverse sectioning, seed coat and endosperm halves were embedded in water agar and incubated as described for drupe tissues. After $48 \mathrm{~h}$, all cultures were examined microscopically $(\times 200)$ for identification

Table 1. Effect of fungicide programs and application schedules on the number of infected plants and the area under disease progress curve (AUDPC) values for management of Alternaria panax on ginseng during the 2005 to 2007 growing seasons ${ }^{\mathrm{w}}$

\begin{tabular}{|c|c|c|c|c|c|c|c|c|c|}
\hline \multirow[b]{2}{*}{ Treatments $^{\mathrm{z}}$} & \multicolumn{3}{|c|}{ No. of applications } & \multicolumn{3}{|c|}{ No. of infected plants ${ }^{x}$} & \multicolumn{3}{|c|}{ AUDPC infected plants ${ }^{y}$} \\
\hline & 2005 & 2006 & 2007 & 2005 & 2006 & 2007 & 2005 & 2006 & 2007 \\
\hline Nontreated & 0 & 0 & 0 & $60.3 \mathrm{~b}$ & $133.5 \mathrm{~b}$ & $183.8 \mathrm{c}$ & $36.0 \mathrm{~b}$ & $55.8 \mathrm{~b}$ & $21.3 \mathrm{e}$ \\
\hline 7-day schedule & 16 & 16 & 12 & & & & & & \\
\hline Chlorothalonil & $\ldots$ & $\ldots$ & $\ldots$ & $0.0 \mathrm{a}$ & $7.8 \mathrm{a}$ & $33.0 \mathrm{a}$ & $0.0 \mathrm{a}$ & $1.7 \mathrm{a}$ & $2.1 \mathrm{ab}$ \\
\hline Chlorothalonil/pyraclostrobin & $\ldots$ & $\ldots$ & $\ldots$ & $0.0 \mathrm{a}$ & $1.8 \mathrm{a}$ & $11.5 \mathrm{a}$ & $0.0 \mathrm{a}$ & $0.4 \mathrm{a}$ & $1.1 \mathrm{a}$ \\
\hline Copper hydroxide/pyraclostrobin & $\ldots$ & $\ldots$ & $\ldots$ & $0.0 \mathrm{a}$ & $0.8 \mathrm{a}$ & $19.8 \mathrm{a}$ & $0.0 \mathrm{a}$ & $0.2 \mathrm{a}$ & $1.6 \mathrm{a}$ \\
\hline 10-day schedule & 10 & 12 & 8 & & & & & & \\
\hline Chlorothalonil & $\ldots$ & $\ldots$ & $\ldots$ & $0.0 \mathrm{a}$ & $9.0 \mathrm{a}$ & $134.3 \mathrm{ab}$ & $0.0 \mathrm{a}$ & $2.3 \mathrm{a}$ & $8.8 \mathrm{abcd}$ \\
\hline Chlorothalonil/pyraclostrobin & $\ldots$ & $\ldots$ & $\ldots$ & $0.0 \mathrm{a}$ & $2.3 \mathrm{a}$ & $120.0 \mathrm{ab}$ & $0.0 \mathrm{a}$ & $0.5 \mathrm{a}$ & $6.7 \mathrm{abc}$ \\
\hline Copper hydroxide/pyraclostrobin & $\ldots$ & $\ldots$ & $\ldots$ & $0.5 \mathrm{a}$ & $7.0 \mathrm{a}$ & $191.5 \mathrm{c}$ & $0.6 \mathrm{a}$ & $2.0 \mathrm{a}$ & $9.9 \mathrm{bcd}$ \\
\hline TOM-CAST 10 DSV schedule & 10 & 7 & 4 & & & & & & \\
\hline Chlorothalonil & $\ldots$ & $\ldots$ & $\ldots$ & $0.0 \mathrm{a}$ & $42.3 \mathrm{a}$ & $170.5 \mathrm{c}$ & $0.0 \mathrm{a}$ & $11.5 \mathrm{a}$ & $13.7 \mathrm{~cd}$ \\
\hline Chlorothalonil/pyraclostrobin & $\ldots$ & $\ldots$ & $\ldots$ & $0.0 \mathrm{a}$ & $6.5 \mathrm{a}$ & $42.5 \mathrm{a}$ & $0.0 \mathrm{a}$ & $1.6 \mathrm{a}$ & $4.1 \mathrm{ab}$ \\
\hline Copper hydroxide/pyraclostrobin & $\ldots$ & $\ldots$ & $\ldots$ & $0.0 \mathrm{a}$ & $10.5 \mathrm{a}$ & $79.3 \mathrm{ab}$ & $0.0 \mathrm{a}$ & $2.8 \mathrm{a}$ & $7.0 \mathrm{abc}$ \\
\hline TOM-CAST 15 DSV schedule & 6 & 5 & 3 & & & & & & \\
\hline Chlorothalonil & $\ldots$ & $\ldots$ & $\ldots$ & $0.0 \mathrm{a}$ & $26.5 \mathrm{a}$ & $175.0 \mathrm{c}$ & $0.0 \mathrm{a}$ & $9.2 \mathrm{a}$ & $13.6 \mathrm{~cd}$ \\
\hline Chlorothalonil/pyraclostrobin & $\ldots$ & $\ldots$ & $\ldots$ & $0.0 \mathrm{a}$ & $21.0 \mathrm{a}$ & $80.3 \mathrm{ab}$ & $0.0 \mathrm{a}$ & $5.1 \mathrm{a}$ & $6.4 \mathrm{abc}$ \\
\hline Copper hydroxide/pyraclostrobin & $\ldots$ & $\ldots$ & $\ldots$ & $0.0 \mathrm{a}$ & $38.5 \mathrm{a}$ & $184.8 \mathrm{c}$ & $0.0 \mathrm{a}$ & $10.5 \mathrm{a}$ & $15.4 \mathrm{~d}$ \\
\hline
\end{tabular}

${ }^{\mathrm{w}}$ Column means followed by the same letter are not significantly different (Student-Newman-Keuls, $P=0.05$ ).

${ }^{x}$ Mean number of A. panax-infected plants per $3 \mathrm{~m}$ of treated garden section on the final rating date.

${ }^{\mathrm{y}}$ Mean AUPDC values per $3 \mathrm{~m}$ of treated garden section on the final rating date.

${ }^{\mathrm{z}}$ Chlorothalonil was applied at $0.68 \mathrm{~kg}$ a.i./ha, pyraclostrobin at $0.07 \mathrm{~kg}$ a.i./ha, and copper hydroxide at $0.73 \mathrm{~kg}$ a.i./ha. DSV $=$ disease severity value. 
of fungi. Alternaria spp. were identified as A. alternata according to Lagopodi and Thanassoulopoulos (17) (average conidium, 30.4 by $11.1 \mu \mathrm{m}$ ) or as $A$. panax according to Brammall (5) (average conidium, 150 to 160 by 12 to $20 \mu \mathrm{m}$ ). The percentage of Alternaria spp. isolated from both drupe and seed tissues were subjected to ANOVA and a Student-Newman-Keuls significant difference test as previously described.

Following cold storage, the remaining drupes were macerated by hand and the seeds removed. Seeds were soaked for 5 min in a $10 \%$ bleach solution, triple rinsed with distilled water, and allowed to air dry before weighing. Seed and drupe weights were also statistically analyzed.

\section{RESULTS}

Evaluation of fungicide programs and spray schedules with TOM-CAST. The 7-day schedule resulted in 16 sprays in 2005 and 2006 and 12 sprays in 2007. The 10-day schedule resulted in 10 (2005), 12 (2006), and 8 (2007) applications. The TOM-CAST 10 DSV schedule prompted 10, 7, and 4 applications and the 15 DSV schedule prompted 6,5 , and 3 fungicide applications in 2005 (89 total DSVs), 2006 (83 total DSVs), and 2007 (57 total DSVs), respectively.

In each year of the study, Alternaria blight resulted in premature defoliation and death of nontreated plants. In 2005 and 2006, all fungicide programs were similar and limited foliar blight compared with the nontreated control (Table 1; Fig. 1). Similar results were seen for 2005 and 2006 AUDPC data (Table 1). In 2007, disease pressure was greater. The 7-day schedule, regardless of fungicide program, significantly limited numbers of infected plants compared with the nontreated control (Fig. 1; Table 1). Across all years tested, the following treatment programs were similar to the 7-day treatments in numbers of plants infected: chlorothalonil applied every 10 days, chlorothalonil/pyraclostrobin applied every 10-days and according to TOM-CAST $10 \mathrm{DSV}$ and $15 \mathrm{DSV}$ schedules, and copper hydroxide/pyraclostrobin applied according to TOM-CAST 10 DSV (Table 1). However, according to the AUDPC data, only chlorothalonil/ pyraclostrobin applied every 10 days or according to TOM-CAST 10 and 15 DSV schedules and copper hydroxide/pyraclostrobin applied according to TOM-CAST 10 DSV provided consistent season-long protection similar to the 7-day schedules (Table 1). Phytotoxicity was not observed with any of the treatments.

Regardless of the fungicide program, the fresh weights of the drupes were significantly higher for treatments sprayed every 7 days compared with all other treatments and the nontreated control (Table 2). The seed weight was significantly greater for the treatments applied every 7 days, re- gardless of fungicide program, when compared with the nontreated control. The weight of the seed from plots treated with chlorothalonil/pyraclostrobin every 10 days or according to TOM-CAST 10 and 15 DSV schedules was similar to that resulting from the 7-day schedule (Table 2) but was not significantly different from the nontreated control. Similarly, copper hydroxide/pyraclostrobin applied every 10 days or according to TOM-CAST 10 DSV resulted in seed weight similar to the 7-day schedule but was not significantly different than the nontreated control.

After the drupe tissue was incubated for $48 \mathrm{~h}$, A. alternata and A. panax were iso- lated from all treatments (Table 3). Only copper hydroxide/pyraclostrobin applied to plants every 10 days significantly reduced the incidence of $A$. panax on drupes and seed coats compared with the nontreated control. A. panax was not detected on any of the seed endosperms, regardless of treatment (data not shown). A. alternata was commonly found on the drupe, seed coat, and endosperm tissue. Only a 7-day treatment of chlorothalonil alternated with pyraclostrobin significantly reduced the occurrence of A. alternata on the drupe and seed coat compared with the nontreated and all other treatments.
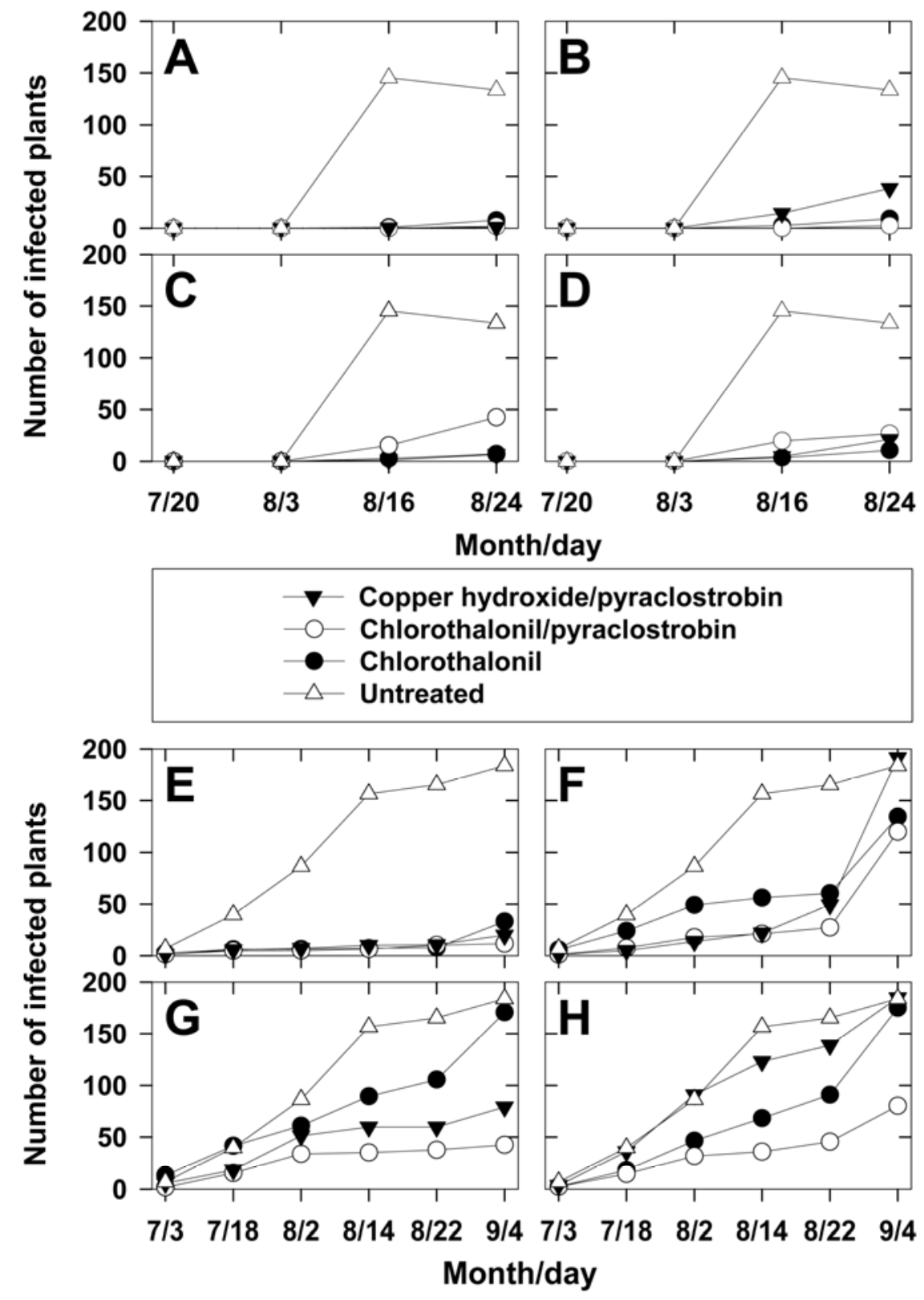

Fig. 1. Disease progress curves for Alternaria panax infection of 4-year-old ginseng plants not treated or treated with the fungicide chlorothalonil ( $0.68 \mathrm{~kg}$ a.i./ha), chlorothalonil $(0.68 \mathrm{~kg}$ a.i./ha) alternated with pyraclostrobin $(0.07 \mathrm{~kg}$ a.i./ha), or copper hydroxide $(0.73 \mathrm{~kg}$ a.i./ha) alternated with pyraclostrobin (0.07 kg a.i./ha). Fungicide programs were scheduled during the 2006 growing season every A, 7 or B, 10 days; or according to the TOM-CAST disease forecaster using disease severity values (DSVs) of C, 10 or D, 15 DSV. Fungicide programs were scheduled during the 2007 growing season every $\mathbf{E}, 7$ or $\mathbf{F}, 10$ days; or according to the TOM-CAST disease forecaster using $\mathbf{G}, 10$ or $\mathbf{H}, 15$ DSV. 


\section{DISCUSSION}

Alternaria leaf blight on ginseng is especially destructive, causing rapid defoliation and plant death when left nontreated. Without effective control measures, growers risk reduced root yields or losing entire plantings (5). Wisconsin and Michigan ginseng growers currently rely on fungicides to manage Alternaria blight during the relatively long growing season of May through September. Ginseng growers must tect the crop while complying with the labeled seasonal application limits. apply fungicide sprays judiciously to pro-

Optimizing fungicide applications by using a disease forecaster with reducedrisk fungicides may offer an integrated pest management (IPM) strategy suitable for ginseng production. A conservative threshold (10 DSV) of TOM-CAST used with an alternating program of chlorothalonil and pyraclostrobin provided control equivalent to 7-day applications. Under moderate disease pressure, fungicides applied according to TOM-CAST 10 or 15 DSVs adequately protected the crop foliage. In 2007, DSVs did not accumulate quickly and fewer fungicide treatments

Table 2. Effects of fungicide programs and application schedule in management of Alternaria panax on drupe and seed weight in 2007

\begin{tabular}{lrc}
\hline & \multicolumn{2}{c}{${\text { Fresh weight }(\mathbf{g})^{\mathbf{y}}}$} \\
\cline { 2 - 3 } Treatments & Drupe & Seed \\
\hline Nontreated & $25.7 \mathrm{~b}$ & $11.1 \mathrm{~b}$ \\
7-day schedule & & \\
$\quad$ Chlorothalonil & $515.4 \mathrm{a}$ & $118.7 \mathrm{a}$ \\
Chlorothalonil/pyraclostrobin & $618.6 \mathrm{a}$ & $143.7 \mathrm{a}$ \\
Copper hydroxide/pyraclostrobin & $602.9 \mathrm{a}$ & $142.9 \mathrm{a}$ \\
10-day schedule & & \\
$\quad$ Chlorothalonil & $67.1 \mathrm{~b}$ & $21.1 \mathrm{~b}$ \\
Chlorothalonil/pyraclostrobin & $177.1 \mathrm{~b}$ & $53.9 \mathrm{ab}$ \\
Copper hydroxide/pyraclostrobin & $176.7 \mathrm{~b}$ & $53.8 \mathrm{ab}$ \\
TOM-CAST 10 DSV schedule & & \\
Chlorothalonil & $47.9 \mathrm{~b}$ & $20.4 \mathrm{~b}$ \\
Chlorothalonil/pyraclostrobin & $243.1 \mathrm{~b}$ & $62.3 \mathrm{ab}$ \\
Copper hydroxide/pyraclostrobin & $188.6 \mathrm{~b}$ & $54.9 \mathrm{ab}$ \\
TOM-CAST 15 DSV schedule & & \\
Chlorothalonil & $44.2 \mathrm{~b}$ & $16.4 \mathrm{~b}$ \\
Chlorothalonil/pyraclostrobin & $272.2 \mathrm{~b}$ & $75.6 \mathrm{ab}$ \\
Copper hydroxide/pyraclostrobin & $33.1 \mathrm{~b}$ & $13.9 \mathrm{~b}$ \\
\hline
\end{tabular}

${ }^{y}$ Column means followed by the same letter are not significantly different (Student-Newman-Keuls, $P$ $=0.05$ ).

${ }^{\mathrm{z}}$ Number of fungicide applications scheduled according to timing intervals of 7 days $=16$ (2005 and 2006) and 12 (2007); 10 days $=10$ (2005), 12 (2006), and 8 (2007); 10 disease severity value (DSV) $=10$ (2005), 7 (2006), and 4 (2007); and 15 DSV = 6 (2005), 5 (2006), and 3 (2007). Chlorothalonil was applied at $0.68 \mathrm{~kg}$ a.i./ha, pyraclostrobin at $0.07 \mathrm{~kg}$ a.i./ha, and copper hydroxide at $0.73 \mathrm{~kg}$ a.i./ha. were prompted. Some of the TOM-CAST programs that included pyraclostrobin provided control similar to the 7-day programs. Initial inoculum levels in 2007 may have been higher than in 2005 and 2006, increasing disease pressure.

Although TOM-CAST 15 DSV is a practical and economical alternative to calendar-based applications in asparagus (18), carrot (3), and tomato (6), high-value crops such as celery and ginseng pose unique challenges. Carrot plants can tolerate some Alternaria leaf blight and Cercospora leaf spot (caused by A. dauci and Cercospora carotae, respectively) as long as they can withstand the mechanical harvesting which pulls the roots from the ground (3). Also, these foliar pathogens do not typically defoliate the crop as rapidly as observed with $A$. panax on ginseng. Similarly, purple spot of asparagus (incited by Stemphylium vesicarium) causes premature browning and defoliation of the photosynthetic tissue but consecutive years of premature defoliation is required before yield is reduced (18). Carrot and asparagus are valued at $\$ 3,424$ and $\$ 2,420 / \mathrm{ha}$, respectively (2), whereas celery and ginseng root average $\$ 20,431 /$ ha (2) and $\$ 13,930 /$ ha (11), respectively. There is no tolerance for late blight on celery incited by $S$. apiicola because the marketable portion of the celery is affected and consumers demand unblemished product (2). Similarly, A. panax cannot be tolerated in a ginseng crop because of its ability to rapidly blight and defoliate the crop, negatively affecting root and seed yield.

Ginseng seed yield and quality is an important consideration when assessing fungicide programs. Current market prices for stratified seed are $\$ 55 / \mathrm{kg}$. With an average seed yield of $336.3 \mathrm{~kg} / \mathrm{ha}$, each hectare

Table 3. Effect of fungicide programs and application schedules on recovery of Alternaria spp. from drupe, seed coat, and endosperm tissues in 2007

\begin{tabular}{|c|c|c|c|c|c|}
\hline \multirow[b]{3}{*}{ Treatments $^{\mathrm{z}}$} & \multicolumn{5}{|c|}{ Alternaria spp. recoveredy } \\
\hline & \multicolumn{2}{|c|}{ A.panax } & \multicolumn{3}{|c|}{ A. alternata } \\
\hline & Drupe & Coat & Drupe & Coat & Endosperm \\
\hline Nontreated & $100.0 \mathrm{~b}$ & $100.0 \mathrm{~b}$ & $100.0 \mathrm{~b}$ & $100.0 \mathrm{~d}$ & $67.0 \mathrm{a}$ \\
\hline \multicolumn{6}{|l|}{ 7-day schedule } \\
\hline Chlorothalonil & $60.0 \mathrm{ab}$ & $60.0 \mathrm{ab}$ & $18.0 \mathrm{~b}$ & $17.5 \mathrm{bcd}$ & $11.0 \mathrm{ab}$ \\
\hline Chlorothalonil/pyraclostrobin & $45.0 \mathrm{ab}$ & $45.0 \mathrm{ab}$ & $7.8 \mathrm{a}$ & $3.0 \mathrm{a}$ & $5.0 \mathrm{ab}$ \\
\hline Copper hydroxide/pyraclostrobin & $55.0 \mathrm{ab}$ & $55.0 \mathrm{ab}$ & $14.0 \mathrm{~b}$ & $10.0 \mathrm{bc}$ & $14.0 \mathrm{ab}$ \\
\hline \multicolumn{6}{|l|}{ 10-day schedule } \\
\hline Chlorothalonil & $70.0 \mathrm{ab}$ & $70.0 \mathrm{ab}$ & $80.0 \mathrm{~b}$ & $45.0 \mathrm{~b}$ & $65.0 \mathrm{ab}$ \\
\hline Chlorothalonil/pyraclostrobin & $75.0 \mathrm{ab}$ & $75.0 \mathrm{ab}$ & $70.0 \mathrm{~b}$ & $87.5 \mathrm{bcd}$ & $50.0 \mathrm{ab}$ \\
\hline Copper hydroxide/pyraclostrobin & $40.0 \mathrm{a}$ & $40.0 \mathrm{a}$ & $100.0 \mathrm{~b}$ & $70.0 \mathrm{bcd}$ & $39.0 \mathrm{ab}$ \\
\hline \multicolumn{6}{|l|}{ TOM-CAST 10 DSV schedule } \\
\hline Chlorothalonil & $70.0 \mathrm{ab}$ & $70.0 \mathrm{ab}$ & $84.0 \mathrm{~b}$ & $65.0 \mathrm{bcd}$ & $37.5 \mathrm{ab}$ \\
\hline Chlorothalonil/pyraclostrobin & $97.5 \mathrm{~b}$ & $97.5 \mathrm{~b}$ & $100.0 \mathrm{~b}$ & $100.0 \mathrm{~d}$ & $85.0 \mathrm{~b}$ \\
\hline Copper hydroxide/pyraclostrobin & $52.5 \mathrm{ab}$ & $52.5 \mathrm{ab}$ & $100.0 \mathrm{~b}$ & $100.0 \mathrm{~d}$ & $67.5 \mathrm{ab}$ \\
\hline \multicolumn{6}{|l|}{ TOM-CAST 15 DSV schedule } \\
\hline Chlorothalonil & $100.0 \mathrm{~b}$ & $100.0 \mathrm{~b}$ & $100.0 \mathrm{~b}$ & $94.0 \mathrm{~cd}$ & $37.5 \mathrm{ab}$ \\
\hline Chlorothalonil/pyraclostrobin & $100.0 \mathrm{~b}$ & $100.0 \mathrm{~b}$ & $100.0 \mathrm{~b}$ & $84.0 \mathrm{bcd}$ & $41.3 \mathrm{ab}$ \\
\hline Copper hydroxide/pyraclostrobin & $100.0 \mathrm{~b}$ & $100.0 \mathrm{~b}$ & $100.0 \mathrm{~b}$ & $100.0 \mathrm{~d}$ & $40.0 \mathrm{ab}$ \\
\hline
\end{tabular}

y Percentage of infected seeds per $3 \mathrm{~m}$ of treated garden section. Column means followed by the same letter are not significantly different (Student-NewmanKeuls, $P=0.05$ ).

${ }^{\mathrm{z}}$ Number of fungicide applications scheduled according to timing intervals of 7 days = 16 (2005 and 2006) and 12 (2007); 10 days = 10 (2005), 12 (2006), and 8 (2007); 10 disease severity value (DSV) = 10 (2005), 7 (2006), and 4 (2007); and 15 DSV = 6 (2005), 5 (2006), and 3 (2007). Chlorothalonil was applied at $0.68 \mathrm{~kg}$ a.i./ha, pyraclostrobin at $0.07 \mathrm{~kg}$ a.i./ha, and copper hydroxide at $0.73 \mathrm{~kg}$ a.i./ha. 
represents a value of $\$ 18,537$. Even when fungicide programs were adequate, seed yield and quality was not always acceptable. Sprays according to TOM-CAST 10 or $15 \mathrm{DSV}$ or every 10 days resulted in reduced seed weights compared with spraying every 7 days. Future research will test a hybrid program whereby TOMCAST 10 DSV with chlorothalonil and pyraclostrobin is used from plant emergence to flowering (mid- to late June), after which fungicides are applied every 7 days to protect developing seed from becoming infected by A. panax inoculum. As ginseng growers harvest their own seed for planting and to sell to other growers, therefore, the potential seed dissemination of Alternaria is an important component of overall disease management and must be addressed for an IPM program to be successful. In our studies, A. panax was prevalent on the ginseng drupe and seed coat. Although A. panax was not isolated from the endosperm in this study, previous seed samples from ginseng growers submitted for diagnosis have often yielded this pathogen from the endosperm tissue (13).

In addition to $A$. panax, $A$. alternata was recovered from ginseng seed. A. alternata is often encountered on other ginseng tissue, including stem and leaves submitted for diagnostic evaluation (S. N. Hill, unpublished data). The impact of $A$. alternata associated with seed tissues on viability and crop health is unknown.

Considering the chemical control measures needed to maintain commercial ginseng gardens, continued efforts to explore methods to reduce sprays without risking crop health are desirable. Alternating applications of fungicides with different modes of action is critical due to restrictions on numbers of applications or amounts of fungicides per season and to delay development of resistance in the pathogen. In our study, alternating chlorothalonil with pyraclostrobin provided protection of the foliage and seed. Because all fungicide programs tested in our project exceeded seasonal label allowances, growers must incorporate additional labeled fungicides (i.e., mancozeb or boscalid) into their management programs. Although these products were not included in this study, field studies have been conducted that tested these fungicides against Alternaria and indicated that mancozeb and boscalid would be helpful (12).

\section{ACKNOWLEDGMENTS}

This work was funded by the United States Department of Agriculture Cooperative State Research, Education, and Extension Service Pest
Management Alternatives Program Award 200334381-13522. We thank B. R. Harlan and D. Reif for technical assistance, S. Linderman for assistance in manuscript preparation, and the Ginseng Board of Wisconsin and Wisconsin Ginseng Growers Association for samples and collaboration.

\section{LITERATURE CITED}

1. Adam, K. L. 2004. Ginseng, goldenseal and other native roots. Hortic. Tech. Note ATTRA Publ. No. IP115.

2. Bounds, R. S., and Hausbeck, M. K. 2007. Comparing disease predictors and fungicide programs for late blight management in celery. Plant Dis. 91:532-538.

3. Bounds, R. S., Hausbeck, M. K., and Podolsky, R. H. 2006. Comparing disease forecasters for timing fungicide sprays to control foliar blight on carrot. Plant Dis. 90:264-268.

4. Bourke, P. M. A. 1970. Use of weather information in the prediction of plant disease epiphytotics. Annu. Rev. Phytopathol. 12:345370.

5. Brammall, R. 1994. Ginseng. Pages 294-295 in: Diseases and Pests of Vegetable Crops in Canada. R. J. Howard, J. A. Garland, and W. L. Sutton, eds. Phytopathol. Soc. Entomol. Soc. of Canada, Ottawa, ON, Canada.

6. Byrne, J. M., Hausbeck, M. K., and Latin, R. X. 1997. Efficacy and economics of management strategies to control anthracnose fruit rot in processing tomatoes in the Midwest. Plant Dis. $81: 1167-1172$.

7. Chang, K. F., Howard, R. J., Gaudiel, R. G., and Hwang, S. F. 1997. The occurrence of ginseng diseases in Alberta in 1996. Can. Plant Dis. Surv. 77:78-80.

8. Chang, K. F., Howard, R. J., Gaudiel, R. G., Hwang, S. F., and Blade, S. F. 1998. Diseases of ginseng in Alberta in 1997. Can. Plant Dis. Surv. 78:89-91.

9. Davis, J., and Shoemaker, P. B. 1999. Ginseng disease control-Phytophthora and Alternaria. Ext. Bull. No. 132. North Carolina State University, Raleigh.

10. Hausbeck, M. K. 2004. Pest management in the future. A strategic plan for the Michigan and Wisconsin ginseng industry. USDA Regional IPM Centers, Center Products, PMSPs, Ginseng, archived, 04/13/2004. Online publication.

11. Hausbeck, M. K. 2007. Pest management in the future. A strategic plan for the Michigan and Wisconsin ginseng industry. USDA Regional IPM Centers, Center Products, PMSPs, Ginseng, 12/14/2007. Online publication.

12. Hausbeck, M. K., and Harlan, B. R. 2004. Effectiveness of registered and unregistered fungicides to control Alternaria blight on ginseng. Fungic. Nematicide Tests 60:V021.

13. Hill, S. N., and Hausbeck, M. K. 2008. Pathology and treatment of American ginseng seed. (Abstr.) Phytopathology 98:S67.

14. Joy, A. E., and Parke, J. L. 1995. Biocontrol of Alternaria leaf blight on American ginseng by Burkholderia cepacia AMMD. Pages 93-100 in: The Challenges of the 21 st Century-Proc. Int. Ginseng Conf. Vancouver. W. G. Bailey, C. Whitehead, J. T. A. Proctor, and J. T. Kyle, eds. Simon Fraser University, Burnaby, BC, Canada.

15. Krause, R. A., and Massie, L. B. 1975. Predictive systems: Modern approaches to disease control. Annu. Rev. Phytopathol. 17:31-47.

16. Laemmlen, F. 2001. Alternaria diseases. Publ No. 8040. Regents of University of California, Division of Agriculture and Natural Resources, Oakland.

17. Lagopodi, A. L., and Thanassoulopoulos, C. C. 1995. Development of chlamydospores in $\mathrm{Al}$ ternaria alternata. Mycologia 87:588-591.

18. Meyer, M. P., Hausbeck, M. K., and Podolsky, R. 2000. Optimal fungicide management of purple spot of asparagus and impact on yield Plant Dis. 84:525-530.

19. Miller, S. A., Colburn, G. C., and Evans, W. B. 1999. Management of Septoria leaf light of parsley with fungicides and efficacy of a disease predictive model. (Abstr.) Phytopathology 89:S53.

20. Ott, R. L., and Longnecker, M. 2001. An Introduction to Statistical Methods and Data Analysis, 5th ed. Duxbury Press, Pacific Grove, CA.

21. Parke, J. L., and Gurian-Sherman, D. 2001 Diversity of the Burkholderia cepacia complex and implications for risk assessment of biological control strains. Annu. Rev. Phytopathol. 39:225-258.

22. Parke, J. L., and Shotwell, K. M. 1989. Diseases of cultivated ginseng. Univ. Wisc. Madison Agric. Exp. Stn. Publ. No. 3465.

23. Pitblado, R. E. 1992. The development and implementation of TOM-CAST. Ontario Ministry of Agriculture and Food, Ridgetown, ON, Canada.

24. Pritts, K. D. 1995. Ginseng: How to Find, Grow and Use America's Forest Gold. Stackpole Books, Mechanicsburg, PA.

25. Putnam, M. L., and du Toit, L. J. 2003. First report of Alternaria blight caused by Alternaria panax on ginseng (Panax quinquefolium) in Oregon and Washington, USA. Plant Pathol. 52:406

26. Quayyum, H. A., Dobinson, K. F., and Traquair, J. A. 2005. Conidial morphology, virulence, molecular characterization and hostparasite interaction of selected Alternaria panax isolates on American ginseng. Can. J. Bot. 83:1133-1143.

27. Rahimian, M. K. 1987. Resistance of Alternaria panax to iprodione under field conditions. (Abstr.) Phytopathology 77:1747.

28. Scott, J. A., Rogers, S., Cooke, D., and Fry, B L. 1995. Woods-grown ginseng. West Va. Univ. Ext. Serv. Agric. Field Crops. Online publication.

29. Shaner G., and Finney, R. E. 1977. The effect of nitrogen fertilization on the expression of slow-mildewing resistance in Knox wheat. Phytopathology 67:1051-1056.

30. Uchida, J. A. 2003. Alternaria panax. University of Hawaii; College of Tropical Agriculture and Human Resources; Extension/Outreach; Commercial Agriculture; Knowledge Master; Crop Knowledge Master; Information on Agricultural Pests; Pest Search/By Scientific Name; Plant Disease Pathogens; Alternaria panax. Online publication.

31. Webster, B. J., and Hausbeck, M. K. 2006. Evaluation of reduced-risk fungicides and biopesticides for control of Alternaria blight of ginseng, 2005. Fungic. Nematicide Tests 61:V065.

32. Zadocks, J. C. 1984. A quarter century of disease warning: 1958-1983. Plant Dis. 68:352-355. 